\title{
ANALYSIS OF BODY MASS INDEX (BMI) OF SAMPLE HOUSEHOLDS: SANGLI DISTRICT (MH) INDIA
}

\section{VINOD B. WAGHMARE}

Research Student, Department of Economics Shivaji University, Maharashtra, India

\begin{abstract}
Body mass index (BMI) of sample households in Sangli district (MH) is one of the important measures for the measurement of household food security. Availability, access, stabilization and utilization are four pillars of food security. When senses all these pillars in the root you assumed that analyzing of body mass index. Drought and nondrought areas were chosen for comparatively study. 340 households were selected for analysis, body mass index (BMI) of nearby 1700 family members were calculated. Calculating BMI was divided into underweight, normal, or overweight and obesity categories and were comparatively studied for different results. Analysis of body mass index (BMI) into underweight and obesity as per age groups of respondents. For social justice, (BMI) analysis categories were General, $O B C, S C / S T$, and NT category wise. Classifications of respondents were also on the basis of size of households and body mass index. Analysis of Type of Ration Card and Body Mass Index of Sample Households. Analysis of Size of Land Holding and Body Mass Index. Suggest suggestion to find out problems in selected study area households

KEYWORDS: Household, Income, Nutrition Level, BMI= (Weight (in kg))/(Height (in meters) $)^{2}$, Consumption Expenditure \& Food Security
\end{abstract}

Received: Jul 04, 2021; Accepted: Jul 24, 2021; Published: Aug 14, 2021; Paper Id.: IJECRDEC20216

\section{INTRODUCTION}

Food security means that individuals and households have access to sufficient food both quantity and quality to meet their nutritional requirement. Man can not live for long without food. Between one half to two-thirds of Indian people do not get food of the right type and between one quarter to one third do not get even enough quantity to eat in order to sustain a healthy active life. He needs a wide range of nutrients to perform various functions of the body and to lead a healthy life. The food that we eat contains nourishing substances called nutrients. There are five main types of nutrients namely carbohydrates, proteins, fats, vitamins and minerals. The food is classified as cereals, pulses, nuts and flesh food fish, meat and eggs. Meat, fish, eggs, and milk as well as pulses and nuts are rich in protein. Dark green, leafy vegetables are a rich source of iron, folic acid, vitamin C and calcium. Many fruits are good sources of vitamin C; vitamin A is present in milk and milk products. India is ranked first and second respectively in the global production of vegetables and fruits. Intake of vegetables, however, is very low, not even a third of the requirement.

Worldwide, around 852 million people are chronically hungry due to extreme poverty, while up to 2 billion people lack food security intermittently due to varying degrees of poverty. The number of people without enough food to eat on a regular basis remains stubbornly high, at over 800 million, and is not falling significantly.

India achieved impressive growth in food production after the adoption of green revolution technology which made the country self-sufficient in basic foods. Total demand for cereals is projected to grow to 218.9 
million tons by the end of the eleventh plan and it would reach 261 million tonnes by the year 2020-21. Demand in India for pulses in the same period would grow to 16.1 and 19.1 million tonnes. Besides, the domestic demand for food grains is expected to reach 280.6 million tonnes by the end of 2020-21.

Food security is one of the major challenges faced by the world today. Food Security is inherently interlinked with other current global challenges of economy. Food security is said to exist when all people at all times, have physical, social \& economic access to sufficient, safe \& nutritious food that meets their dietary needs \& food preferences for active and healthy life (Food Agricultural Organization 2009). However, the distribution of food continues to be problematic and at least 25000 people are recorded to be dying of hunger each day even in the 21 st century.

\subsection{Operational Definition of Concepts/Indicators}

- Household:

- Income:

- Nutrition Level:

$$
\text { BMI }=\frac{\text { Weight }(\text { in kg) }}{\text { Height (in meters) }{ }^{2}}
$$

- IV: Food Security

\subsection{Statement of Research Problem}

The food security programme which was introduced in recent past, it is understood that the percentage of population below the poverty level is almost more than $1 / 4$ there for there is need to study the food security and nutritional level on rural livelihood in the sample area. Food security becomes a reality only at the household level, in fact, at the level of each member of the household. The growing population requires more food production and food security. The main reason for the absence of nutritional security is poor food consumption, less food availability and absence of food grin absorbance knowledge. It is, therefore, present research on the topic of economic analysis of food security and nutritional level on rural livelihood in Sangli district has been chosen and taken up.

\subsection{Scope and Significance of the Study}

In this context promoting livelihood resilience, Food and nutrition security has become central to the policy agenda of the government. Small holder farmers need to be at the centre of this agenda and to play a leading role in investment efforts needed to achieve its food security system provide national food from rural people.

\subsection{Objectives of Research Study}

- To study and analyse the body mass index of sample households of Sangli district.

- To identify the problems and suggest policy measures with regard to food security and nutritional level.

\subsection{Hypotheses}

- Consumption expenditure of food items of underweight (body mass index) respondents was low as compared to overweight and obesity (body mass index) respondents. 


\subsection{Scope and Significance of Research Study}

- It is useful to minimize the inequality in the study area.

- It is important to understand the socio-economic conditions of households in the study area.

- It is important for the planning commission for minimizing poverty and define the poverty line.

\subsection{Research Methodology and Database}

\section{A. Study Area}

Sangli district of Maharashtra state has been selected purposely for the present study.

\section{B. Database}

\section{Primary Data}

Primary data were collected directly from the farmer households with the help of a pre-tested interview schedule. The households of farmers were classified into five distinct categories and first-hand data were collected.

\section{Secondary Data}

The present study exclusively relies on the secondary data, which is collected from the sources such as FAO, Reserve Bank of India's report, CSO data, and Socioeconomic survey of Sangli district by DES Govt. of Maharashtra Mumbai, National Sample Survey Report, and economic survey of Maharashtra state. Census report, reports of the government of Maharashtra etc.

\section{Variables}

The study revealed that the food security and nutritional level depends upon the number of socio-economic analytic variables as given below-

- $\quad$ Body Mass Index (BMI)

- $\quad$ Age group

- Educational level

- Social groups

\section{Sample Size}

Sample Size of Selected Households in Sangli District

\begin{tabular}{|l|l|c|c|c|}
\hline Sangli Districts & \multicolumn{1}{|c|}{ Tahasils } & $\begin{array}{c}\text { Total } \\
\text { Villages }\end{array}$ & Selected Villages & $\begin{array}{c}\text { Selected } \\
\text { Households }\end{array}$ \\
\hline \begin{tabular}{l} 
Low $\begin{array}{l}\text { Develop/Drough } \\
\mathrm{t}\end{array}$ \\
\cline { 2 - 5 }
\end{tabular} & Jat & 125 & $5 \%=6$ & $6 * 20=120$ \\
\hline $\begin{array}{l}\text { Higher Develop/ } \\
\text { Non Drought }\end{array}$ & Miraj & 060 & $5 \%=3$ & $3 * 20=060$ \\
\cline { 2 - 5 } & Walawa & 065 & $5 \%=3$ & $3 * 20=060$ \\
\hline \multicolumn{2}{|r|}{ Total } & $\mathbf{3 4 6}$ & $5 \%=5$ & $\mathbf{3 4 0}$ \\
\hline
\end{tabular}


Percentage change equals the change in value divided by the absolute value of the original value, multiplied by 100.

\section{ANALYSIS OF BODY MASS INDEX (BMI) OF SANGLI DISTRICT}

\subsection{Taluka Wise Analysis of Body Mass Index}

Table 1: Taluka Wise Analysis of Body Mass Index of Sample Respondents

\begin{tabular}{|c|c|c|c|c|c|c|}
\hline \multirow[b]{2}{*}{ Sr. No. } & \multirow[b]{2}{*}{ Talukas } & \multicolumn{5}{|c|}{ BMI } \\
\hline & & $\begin{array}{l}\text { Underweight } \\
\text { (Below 18.5) }\end{array}$ & $\begin{array}{c}\text { Normal } \\
(18.5-24.9) \\
\end{array}$ & $\begin{array}{l}\text { Overweight } \\
(25.0-29.9) \\
\end{array}$ & $\begin{array}{c}\text { Obesity } \\
\text { (30.0 and Above) }\end{array}$ & Total \\
\hline 1 & Jat & $22(18.3)$ & $65(54.2)$ & $24(20.0)$ & $9(7.5)$ & $120(100)$ \\
\hline 2 & Atpadi & $6(10.0)$ & $36(60.0)$ & $14(23.3)$ & $4(6.7)$ & $60(100)$ \\
\hline 3 & Miraj & $2(3.3)$ & $25(41.7)$ & $15(25.0)$ & $18(30.0)$ & $60(100)$ \\
\hline 4 & Walawa & $6(6.0)$ & $49(49.0)$ & $24(24.0)$ & $21(21.0)$ & $100(100)$ \\
\hline \multicolumn{2}{|c|}{ Total } & $36(10.6)$ & $175(51.5)$ & $77(22.6)$ & $52(15.3)$ & $340(100)$ \\
\hline
\end{tabular}

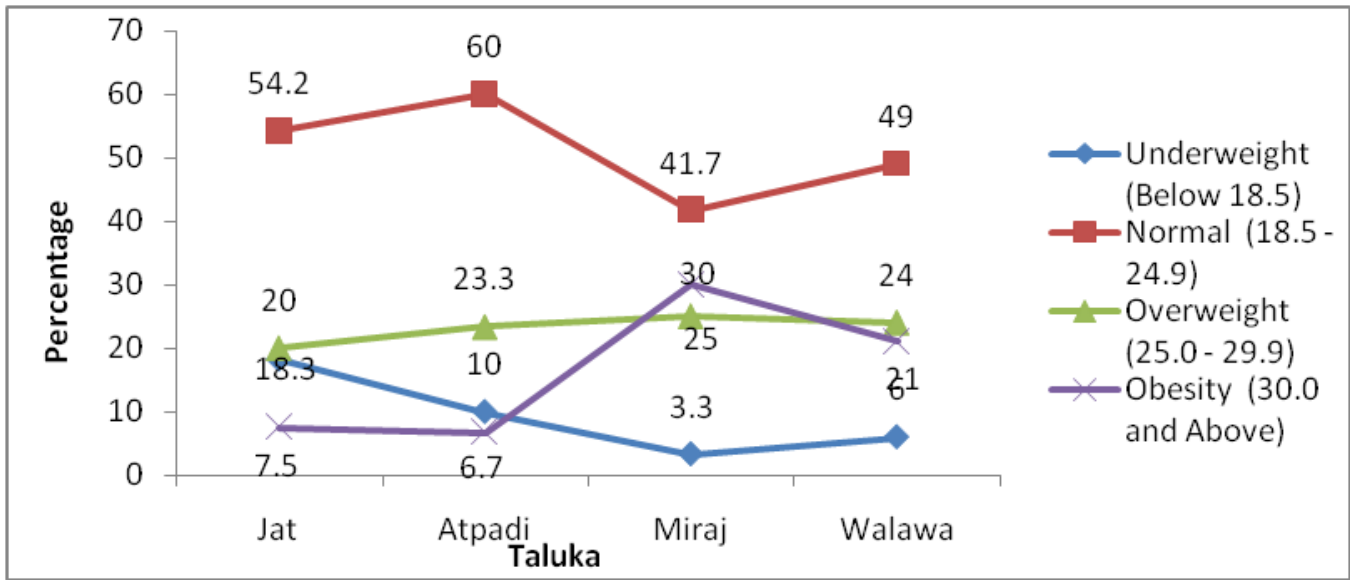

Figure 1: Taluka Wise Analysis of Body Mass Index.

The above table (2.1) shows block wise analysis of body mass index of Sangli district. In the Jat block of Sangli district found that highest i. e. 18.3 percentage of underweight respondents. The highest overweight and obesity respondent finds that in Miraj block i. e. 25 percentage and 30 percentage respectively. The second-highest number of overweight respondents was 23.3 percentage in Atpadi block. The highest body mass index of normal (18.5 to 24.9) was 60 percentage in Atpadi block.

\subsection{Age Group Wise Analysis of Body Mass Index}

Table 2: Age Group Wise Analysis of Body Mass Index of Sample Households

\begin{tabular}{|c|c|c|c|c|c|c|}
\hline \multirow[b]{2}{*}{ Sr. No. } & \multirow[b]{2}{*}{ Age Groups } & \multicolumn{5}{|c|}{ BMI } \\
\hline & & $\begin{array}{l}\text { Underweight } \\
\text { (Below 18.5) }\end{array}$ & $\begin{array}{c}\text { Normal } \\
(18.5-24.9)\end{array}$ & $\begin{array}{c}\text { Overweight } \\
(25.0-29.9)\end{array}$ & $\begin{array}{c}\text { Obesity } \\
\text { (30.0 and Above) }\end{array}$ & Total \\
\hline 1 & Age 0-14 & $0(0.0)$ & $9(64.3)$ & $2(14.3)$ & $3(21.4)$ & $14(100)$ \\
\hline 2 & Age 15-59 & $24(10.8)$ & $113(50.9)$ & $52(23.4)$ & $33(14.9)$ & $222(100)$ \\
\hline 3 & Above 60 & $12(11.5)$ & $53(51.0)$ & $23(22.1)$ & $16(15.4)$ & $104(100)$ \\
\hline & Total & $36(10.6)$ & $175(51.5)$ & $77(22.6)$ & $52(15.3)$ & $340(100)$ \\
\hline
\end{tabular}




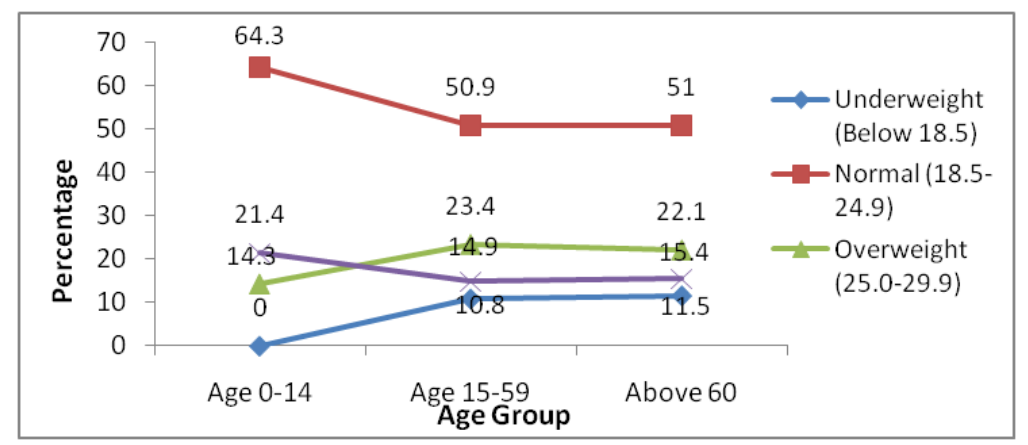

Figure 2: Age Group Wise Analysis of Body Mass Index.

The above table (2.2) shows the classification of body mass index and age group. The underweight respondent of age group 15 to 59 was 10.8 percentages; age group of above 60 was 11.5 percentage. The highest overweight respondent was 23.4 percentage in age group of 15 to 59 and highest obesity was 21.4 percentage in the age group of 0 to 14 .

\subsection{Category Wise Classification of Body Mass Index}

Blow table (3) shows that sample distribution of caste and body mass index of Sangli district. The underweight respondent of general caste was 10.9 percentage, OBC was 8.1 percentage, SC/ST was 5.7 percentage, NT was 18 percentage and total underweight was 10.6 percentage.

Table 3: Category Wise Classification of Body Mass Index of Sample Households of Sangli District

\begin{tabular}{|c|c|c|c|c|c|c|}
\hline \multirow[b]{2}{*}{ Sr. No. } & \multirow[b]{2}{*}{ Caste } & \multicolumn{5}{|c|}{ BMI } \\
\hline & & $\begin{array}{l}\text { Underweight } \\
\text { (Below 18.5) }\end{array}$ & $\begin{array}{c}\text { Normal } \\
(18.5-24.9)\end{array}$ & $\begin{array}{l}\text { Overweight } \\
(25.0-29.9)\end{array}$ & $\begin{array}{c}\text { Obesity } \\
\text { (30.0 and Above) }\end{array}$ & Total \\
\hline 1 & General & $19(10.9)$ & $94(53.7)$ & $33(18.9)$ & $29(16.6)$ & $175(100)$ \\
\hline 2 & $\mathrm{OBC}$ & $5(8.1)$ & $33(53.2)$ & $16(25.8)$ & $8(12.9)$ & $62(100)$ \\
\hline 3 & SC/ST & $3(5.7)$ & $27(50.9)$ & $15(28.3)$ & $8(15.1)$ & $53(100)$ \\
\hline 4 & NT & $9(18.0)$ & $21(42.0)$ & $13(26.0)$ & $7(14.0)$ & $50(100)$ \\
\hline & Total & $36(10.6)$ & $175(51.5)$ & $77(22.6)$ & $52(15.3)$ & $340(100)$ \\
\hline
\end{tabular}

It is found that the highest number of underweight (body mass index) respondents was general category. The highest overweight respondent was SC/ST (28.3 percentage) and the second highest was NT (26 percentage). The table state that the highest number of obesity respondent was general (16.6 percentage) and second-highest obesity was SC/ST (15.1 percentage).

2.4 Analysis of Respondent of Size of Households and Body Mass Index

Table 4: Classifications of Respondents on The Basis of Size of Households and Body Mass Index

\begin{tabular}{|c|c|c|c|c|c|c|}
\hline \multirow[b]{2}{*}{ Sr. No. } & \multirow[b]{2}{*}{ Size of household } & \multicolumn{5}{|c|}{ BMI } \\
\hline & & $\begin{array}{l}\text { Underweight } \\
\text { (Below 18.5) }\end{array}$ & $\begin{array}{c}\text { Normal } \\
(18.5-24.9)\end{array}$ & $\begin{array}{l}\text { Overweight } \\
(25.0-29.9)\end{array}$ & $\begin{array}{c}\text { Obesity } \\
(30.0 \text { and Above) }\end{array}$ & Total \\
\hline 1 & up to 3 members & $3(6.3)$ & $24(50.0)$ & $14(29.2)$ & $7(14.6)$ & $48(100)$ \\
\hline 2 & up to 5 members & $19(11.2)$ & $90(52.9)$ & $39(22.9)$ & $22(12.9)$ & $170(100)$ \\
\hline 3 & up to 7 members & $12(13.8)$ & $48(55.2)$ & $14(16.1)$ & $13(14.9)$ & $87(100)$ \\
\hline 4 & up to 10 members & $2(8.0)$ & $9(36.0)$ & $8(32.0)$ & $6(24.0)$ & $25(100)$ \\
\hline \multirow[t]{2}{*}{5} & above 10 members & $0(0.0)$ & $4(40.0)$ & $2(20.0)$ & $4(40.0)$ & $10(100)$ \\
\hline & Total & $36(10.6)$ & $175(51.5)$ & $77(22.6)$ & $52(15.3)$ & $340(100)$ \\
\hline
\end{tabular}


Above table (4) shows the size of household wise classification of body mass index of sample households of Sangli district. The highest underweight respondent was the size of up to 7 members i.e. 13.8 percentage and the highest overweight respondents was a group of up to 10 member's households. The second highest overweight respondent was a size group of up to 3 members. The highest obesity households were size group of above 10 members i.e. 40 percentage.

\subsection{Analysis of Type of Ration Card and Body Mass Index:}

Table 5: Analysis of Type of Ration Card and Body Mass Index of Sample Households

\begin{tabular}{|c|l|c|c|c|c|c|}
\hline \multirow{2}{*}{ Sr. No. } & \multirow{2}{*}{ Type of Ration Card } & $\begin{array}{c}\text { Underweight } \\
\text { (Below 18.5) }\end{array}$ & $\begin{array}{c}\text { Normal } \\
(\mathbf{1 8 . 5}-\mathbf{2 4 . 9})\end{array}$ & $\begin{array}{c}\text { Overweight } \\
(\mathbf{2 5 . 0}-\mathbf{2 9 . 9})\end{array}$ & $\begin{array}{c}\text { Obesity } \\
(\mathbf{3 0 . 0} \text { and Above) }\end{array}$ & Total \\
\hline 1 & APL(Orange) & $17(10.5)$ & $73(45.1)$ & $47(29.0)$ & $25(15.4)$ & $162(100)$ \\
\hline 2 & BPL(Yellow) & $11(8.6)$ & $71(55.5)$ & $23(18.0)$ & $23(18.0)$ & $128(100)$ \\
\hline 3 & AAY & $6(20.7)$ & $20(69.0)$ & $2(6.90)$ & $1(3.40$ & $29(100)$ \\
\hline 4 & White & $2(9.5)$ & $11(52.4)$ & $5(23.8)$ & $3(14.30$ & $21(100)$ \\
\hline \multicolumn{1}{|c|}{ Total } & $\mathbf{3 6 ( 1 0 . 6 )}$ & $\mathbf{1 7 5}(\mathbf{5 1 . 5})$ & $\mathbf{7 7}(\mathbf{2 2 . 6})$ & $\mathbf{5 2}(\mathbf{1 5 . 3})$ & $\mathbf{3 4 0}(\mathbf{1 0 0})$ \\
\hline \multicolumn{7}{|l|}{ Source: Field Survey, 2019-20 } \\
\hline
\end{tabular}

The above table (5) shows the type of ration card and body mass index wise analysis of sample households of Sangli district. The highest number of households of underweight (below 18.5 Body Mass Index) was AAY (antyodaya annapurnna yojana) ration card holder respondent's i. e. 20.7 percentage. The highest overweight (25 to 29.9 Body Mass Index) respondent was Yellow (APL) ration card holders i.e. 29 percentage and the second-highest overweight respondent was white ration card holder's i. e. 23.8 percentage. The highest number of obesity (30 and above Body Mass Index) was below poverty line ration card (Yellow) holders i.e. 18 percentage.

\subsection{Analysis of Size of Land Holding and Body Mass Index}

Table 6: Analysis of Size of Land Holding and Body Mass Index

\begin{tabular}{|c|c|c|c|c|c|c|}
\hline \multirow[b]{2}{*}{ Sr. No. } & \multirow[b]{2}{*}{ Size of Land Holding } & \multicolumn{5}{|c|}{ BMI } \\
\hline & & $\begin{array}{l}\text { Underweight } \\
\text { (Below 18.5) }\end{array}$ & $\begin{array}{c}\text { Normal } \\
(\mathbf{1 8 . 5 - 2 4 . 9 )}\end{array}$ & $\begin{array}{l}\text { Overweight } \\
(25.0-29.9) \\
\end{array}$ & $\begin{array}{c}\text { Obesity } \\
\text { (30.0 and Above) }\end{array}$ & Total \\
\hline 1 & Below 1 acre & $12(13.5)$ & $40(44.9)$ & $20(22.5)$ & $17(19.1)$ & $89(100)$ \\
\hline 2 & 1 to 2.5 acre & $12(10.4)$ & $61(53.0)$ & $25(21.7)$ & $17(14.8)$ & $115(100)$ \\
\hline 3 & 2.5 to 5 acre & $6(11.1)$ & $34(63.0)$ & $8(14.8)$ & $6(11.1)$ & $54(100)$ \\
\hline 4 & Above 5 acre & $3(8.3)$ & $16(44.4)$ & $11(30.6)$ & $6(16.7)$ & $36(100)$ \\
\hline 5 & No Land & $3(6.5)$ & $24(52.2)$ & $13(28.3)$ & $6(13.0)$ & $46(100)$ \\
\hline & Total & $36(10.6)$ & $175(51.5)$ & 77 (22.6) & $52(15.3)$ & $340(100)$ \\
\hline
\end{tabular}




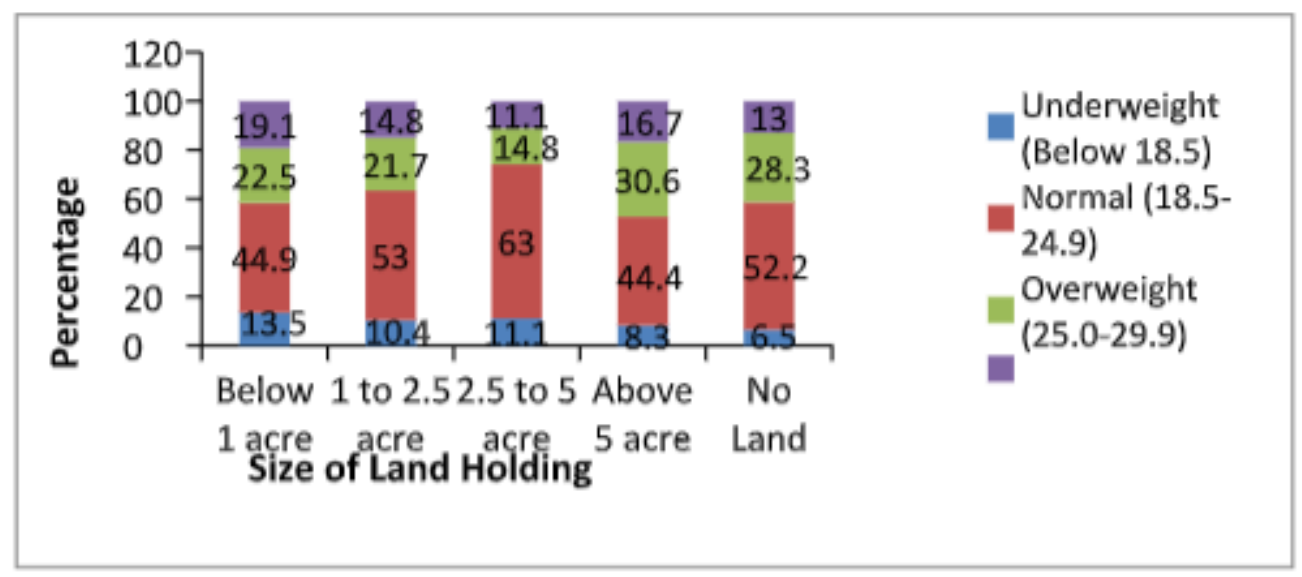

Figure 3: Size of Land Holding and Body Mass Index.

The above table no. 6 states the size of land holding wise analysis of body mass index. The highest underweight (below 18.5 body mass index) respondent was size of land holding of below 1 acre i. e. 13.5 percentage. The highest overweight (25 to 29.9 body mass index) respondent was size of land holding of above 5 acre household's i. e. 30.6 percentage. The highest obesity (30 and above body mass index) respondents was below 1 acre i.e. 19.1 percentage.

\section{HYPOTHESIS TESTING}

H1: Consumption expenditure of food items of underweight (body mass index) respondents was low as compared to overweight and obesity (body mass index) respondents.

Table 7: The Descriptive Statistics

\begin{tabular}{|c|c|c|c|c|c|c|c|c|}
\hline & \multirow{2}{*}{$\mathbf{N}$} & \multirow{2}{*}{ Mean } & \multirow{2}{*}{$\begin{array}{l}\text { Std. } \\
\text { Deviation }\end{array}$} & \multirow{2}{*}{$\begin{array}{l}\text { Std. } \\
\text { Error }\end{array}$} & \multicolumn{2}{|c|}{$\begin{array}{l}\text { 95\% Confidence Interval } \\
\text { for Mean } \\
\end{array}$} & \multirow{2}{*}{ Minimum } & \multirow{2}{*}{ Maximum } \\
\hline & & & & & $\begin{array}{l}\text { Lower } \\
\text { Bound }\end{array}$ & Upper Bound & & \\
\hline $\begin{array}{l}\text { Underweight } \\
\text { (Below 18.5) }\end{array}$ & 36 & 1532.55 & 880.07 & 146.68 & 1234.78 & 1830.32 & 349.00 & 4806.25 \\
\hline $\begin{array}{l}\text { Normal } \\
(18.5-24.9)\end{array}$ & 175 & 1454.29 & 1217.60 & 92.04 & 1272.62 & 1635.95 & 166.00 & 8158.00 \\
\hline $\begin{array}{l}\text { Overweight } \\
(25.0-29.9)\end{array}$ & 77 & 1620.16 & 2024.08 & 230.67 & 1160.75 & 2079.57 & 319.71 & 15880.00 \\
\hline $\begin{array}{l}\text { Obesity } \\
(30.0 \text { and } \\
\text { above) }\end{array}$ & 52 & 1734.33 & 1272.56 & 176.47 & 1380.04 & 2088.61 & 277.63 & 6008.50 \\
\hline Total & 340 & 1542.97 & 1419.18 & 76.97 & $\mathbf{1 3 9 1 . 5 8}$ & 1694.36 & 166.00 & 15880.00 \\
\hline
\end{tabular}

Average expenditure on food items of Underweight respondents is Rs. 1532.55 while this expenditure of Overweight and obesity respondents is 1620.16 and 1734.33 respectively. This statistical significance of Consumption expenditure of food items of underweight, normal, overweight and obesity (body mass index) respondents is tested by using one-way ANOVA classification and Post-Hoc Test. 


\begin{tabular}{|l|c|c|c|c|c|}
\hline \multicolumn{7}{|c|}{ Table: 8: One Way Anova Test } \\
\hline & Sum of Squares & df & Mean Square & F & Sig. \\
\hline Between Groups & 3743152.37 & 3 & 1247717.46 & 0.617 & 0.604 \\
\hline Within Groups & 679028026.76 & 336 & 2020916.75 & & \\
\hline \multicolumn{7}{|c|}{ Total } & $\mathbf{6 8 2 7 7 1 1 7 9 . 1 3}$ & $\mathbf{3 3 9}$ & & & \\
\hline Source: Field Survey, 2019-20 & & \\
\hline
\end{tabular}

In the above One-way ANOVA table F- Value for testing significance of Consumption expenditure of food items of underweight, normal, overweight and obesity (body mass index) respondents is 0.617 and significance value is 0.604 which is insignificant at 5\% (As $\mathbf{0 . 6 0 4 > 0 . 0 5}$ ) level of significance. Hence, we conclude that there is no significant difference in average expenditure of underweight, normal, overweight and obesity.

Table 9: Bonferroni Post Hoc is used to Check which Pair is Different or Statistically Significant

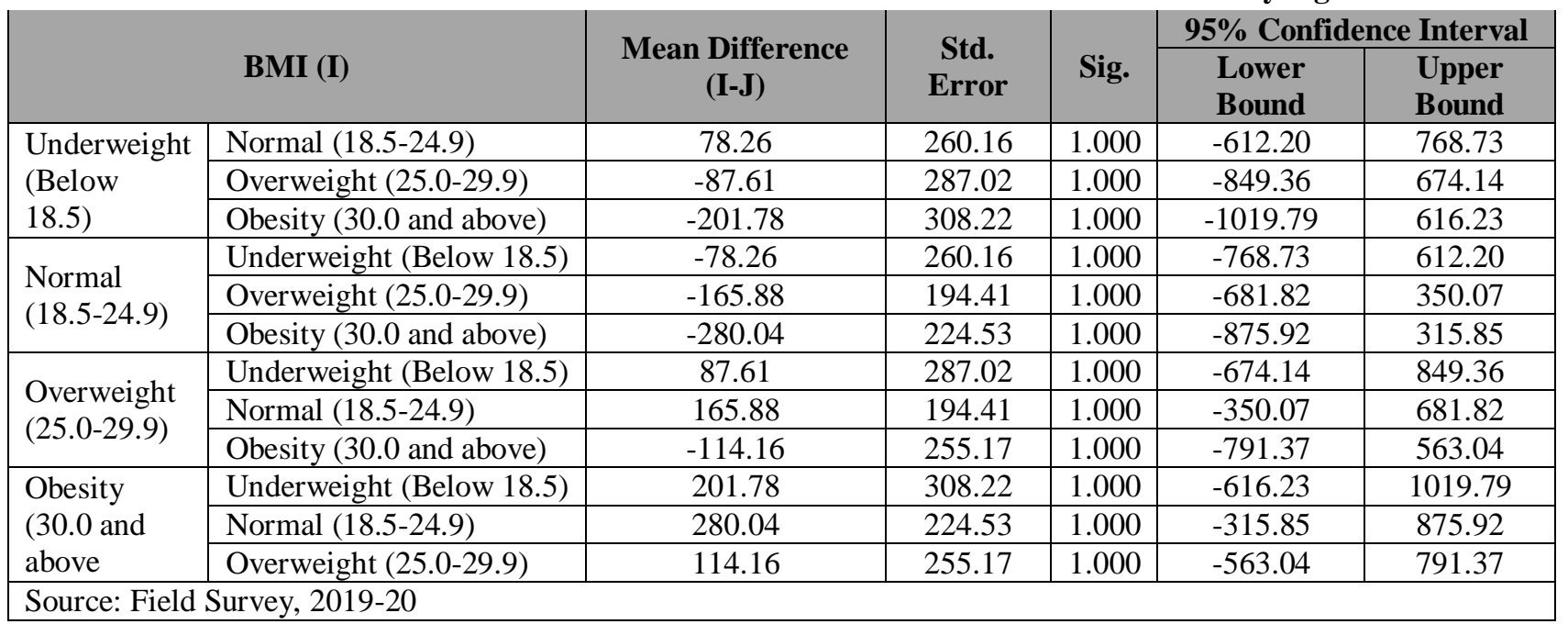

As all significance values are 1.000 hence at $5 \%$ level of significance all pairs are not statistically significant which are already proved in One Way ANOVA. It is concluded that there is no significant difference in the average expenditure of underweight, normal, overweight and obesity

\section{CONCLUSIONS}

This research has discussed the empirical estimates of incidence, intensity and inequality of body mass index, per capita consumption expenditure in terms of quantity consumption and terms of rupees for the households of Sangli district based on the primary data collected during 2019-20. Natural disasters badly affect the agricultural sector because the production of food grains has declined in the drought, fled, earthquake years.

\section{MAJOR FINDINGS}

- The purchasing power of people is highly influenced by the changing lifestyles, the standardof living, modernization and growing employment opportunities.

- We have found that there is a significant difference among the selected blocks and social, religions category. Nutritional status depends upon food availability; availability is higher in taluka level so nutritional status is also higher in the population of Sangli district in Maharashtra. 
- The study confirms that the landless and marginal farmer of Sangli district is poorer than medium and large farmers in average of consumption expenditure and body mass index measures.

\section{REFERENCES}

\section{A. BOOKS}

1. Acharya, S. S \& Agarwal, N. L., (2004). Agricultural Marketing in India, New Delhi,Oxford \& IBH Publishing Company Private Limited

2. Friedman, Milton, (1957): A Theory of the Consumption Function, Princeton: Princeton University Press, 1957.

3. Food and Agriculture Organization, (2012): The state of food insecurity in the world. Rome: FAO printing office

\section{B. ARTICLES AND JOURNALS}

1. King R. P. and Derek B. (1977), Income Distribution, Consumption Patterns and Consumption Linkages in Rural Sierra Leone, African Rural Economy Program, Paper No. 16.

2. Deshmukh, M. S., \& Vyavahare, S. S. (2018). An analysis of consumption expenditure in India. European academic research, 10, 5270-5285.

3. 3.Oldiges C (2012), Cereal consumption and per capita income in India, Economic \& Political Weekly, vol. xlvii no. 6, 11 February, 2012.

4. Amit Basole (2015), Non-Food Expenditures and Consumption Inequality in India, Economic \& Political Weekly, Vol. 50, Issue No. 36, 05 Sep, 2015

\section{REPORTS}

1. Department of Agriculture and Cooperation Directorate of Economics and Statistics. (2012-13). State of Indian agriculture. New Delhi: Government of India Ministry of Agriculture printing office.

2. Department of Agriculture. (2012). A Farmers friendly handbook, for government schemesand programmes. Pune: Government of Maharashtra printing office.

3. Reserve Bank of India. Reserve Bank of India Annual Report since 2001-02 to 2014-15, RBI publication, Mumbai.

4. Socio-Economic review of Sangli district-2012-13.

\section{D.THESIS}

1. Kulkarni S K (1991), A study of consumption pattern in selected rural markets in Sangli districts, Shivaji University, Kolhapur.

2. Pathak A V (1991), Comparative Study of Consumption, Saving and Investment Habits of Salary Earners in Kolhapur, Shivaji University, Kolhapur.

3. Dandage R G (1996), Growth and instability in agriculture production in the drought prone region of Maharashtra state: A regional analysis, Shivaji University, Kolhapur.

4. Barua, Smrita. "Gender Inequality in North East India." International Journal of Humanities and Social Sciences (IJHSS)7.4, Jun - Jul 2018; 103-114

5. More, Shyam, et al. "A Study of Prevalence of Obesity in Adolescents of a Select Primary Urban Health Centre of Navi Mumbai."International Journal of Medicine and Pharmaceutical Science (IJMPS) 5.6, Dec 2015, 39-42 
6. Anitha, R. O. N. D. L. A., Bhoopendra Kumar Singh, and J. Afifa. "An evaluation of drudgery reducing agricultural technologies developed for farm women." International Journal of Agricultural Science and Research 9.2 (2019): 35-42.

7. Al-Asadi, Jasim Naeem. "Perceived stress and eating habits among medical students." International Journal of Medicine and Pharmaceutical Sciences 4.3 (2014): 81-90.

8. Ibrahim, Abdel Sami Musa, ShiWei Xu, and Wen Yu. "Food accessibility, a viability and stability in rural white Nile State of Sudan." International Journal of Agricultural Science and Research (IJASR) 3.4 (2013): 43-55. 